\title{
QUALITY OF LIFE OF PATIENTS PRESCRIBED WITH HERBAL MEDICINE
}

\author{
Dyah Aryani Perwitasari $^{\left.{ }^{*}\right)}$, Nur Mahdi ${ }^{1}$, Mustika Muthaharah ${ }^{1}$, I Nyoman Kertia² \\ ${ }^{1}$ Faculty of Pharmacy, Universitas Ahmad Dahlan, Jl Prof Dr Soepomo, Janturan, Yogyakarta \\ ${ }^{2}$ Faculty of Medicine, Universitas Gadjah Mada, Sekip, Yogyakarta
}

Received May 23, 2016; Accepted August 22, 2016

\begin{abstract}
Herbal medicine has been an alternative treatment, instead of modern medicines. However, some of patients could experience adverse drug reaction (ADR) due to the use of herbal medicines. The $A D R$ can decrease patients' quality of life (QoL). Objective. This study was aimed to understand the QoL of patients prescribed with herbal medicines. Methods. Patients prescribed with herbal medicines as complementary treatment, in two Public Health Centers of Yogyakarta were recruited. The patients were prescribed with herbal medicines one year before this study was started. Naranjo algorithm was used to identify the ADR. The SF-36 questionnaire was given to the patients as the instrument to measure patients' QoL. Results. There were 47 patients participated in this study. Most of the patients are female (62.5\%).Ten patients experienced ADR. There are no significant differences between QoL domains in patients experienced ADR and those without ADR. However, the scores of physical function, role physical, general health, social function, role emotional, and mental health in patients without ADR are higher than those with ADR ( $p>0.05)$. Conclusion. There are no significant differences of QoL between patients with and without ADR. In general, the QoL of patients' without ADR is higher than those with ADR.
\end{abstract}

Keywords: quality of life, SF-36, herbal, Yogyakarta

\section{INTRODUCTION}

Currently the 'back to nature' lifestyle has become widely used in community. Some of the regions in Indonesia want to develop a system related to the development of traditional treatment, alternative and complementary. In 2012, there was an agreement among the leaders of ASEAN countries to support the traditional treatment, alternative and complementary to be integrated in the health care services system (Anonim, 2013). The previous study in China, reported that the quality of life (QoL) of patients with Chinese herbal medicine was higher than patients with usual care. The significant differences were seen from physical, emotional and functional well-being (Han et al, 2016).

Another previous study in Beirut, Lebanon showed that there was $40 \%$ of 180 patients using complementary alternative medicine (CAM). However, there is no significant association between CAM and QoL (Naja et al, 2015). A systematic review reported that the use of Chinese herbal medicine along with chemotherapy in Non Small Cell Lung Cancer can significantly improve the patients' quality of life (Wu et al, 2016). Contradictively, in the group of women with ovarian cancer in China, patients who were treated with traditional chinese medicine during chemotherapy did not show significant improvement of QoL, compared to the patients who only treated with chemotherapy (Chan et al, 2011).

In other disease, which is HIV/AIDS, the use of herbal medicine can significantly improve the mental health of the patients, however there was no significant differences of physical health between patients used herbal medicine and patients did not use herbal medicine (Sugimoto et al, 2005).

The previous studies above, showed that herbal remedies could improve patients' quality of life. In the other hand, herbal medicine is not free from Adverse Drug Reaction (ADR). There is a study in HIV patients that some of herbal 
medicine can cause adverse effect during the antiretroviral treatment and the use of herbal medicine did not increase the patients' QoL (Bepe et al, 2011). Therefore, this study was aimed to understand whether ADR can deteriorate patients' quality of life or not.

\section{METHODS}

\section{Study design}

This study was conducted on June 2015 to December 2015 using cross sectional design

\section{Subjects}

All patients prescribed with herbal medicines as complementary treatment during the study period, in two Public Health Centers of Yogyakarta were recruited in this study. The patients were prescribed with herbal medicines one year before this study was conducted. We recruited all patients and did not use sampling technique due to the limited number of patients prescribed with herbal medicines in Yogyakarta.

\section{Outcome measurement.}

Naranjo algorythm was used to identify the ADR. The SF-36 questionnaire was given to the patients as the instrument to measure patients' quality of life. This study has been approved by Ethical Committe of Universitas Ahmad Dahlan, Yogyakarta, Number 011509069.

\section{Statistical Analysis}

The score of QoL domains were being compared according the the incidence of ADR, using Student-T test analysis.

\section{RESULTS AND DISCUSSION}

There were 47 patients who prescribed with herbal medicine as complementary therapy. Female is the most patient in this study (61.7\%). This could be caused by the fact that woman is more related with the traditional medicine production and like to consume the herbal medicine (Mutmainnah, 2009). The average of age is 53.4 (SD: 15.70). Most of the patients have permanent work. The age range of 15-64 is the productive age for getting the work in Indonesia (BPS, 2016). Some of characteristic date percentage are similar to previous study in China, such as: high school is the most patients' level of education, age percentage of patients $\geq 41$ is more than patients $<41$ and percentage of female is more than male patients (Bepe et al, 2011).

Table 1. Patients' demographic data $(n=47)$

\begin{tabular}{|c|c|}
\hline \multicolumn{2}{|l|}{ Patients' demographic } \\
\hline Age $(\mathrm{X} \pm \mathrm{SD})$ (years) & $53.4 \pm 15.70$ \\
\hline \multicolumn{2}{|l|}{$\operatorname{Sex}(\%)$} \\
\hline Female & 61.7 \\
\hline Male & 38.3 \\
\hline \multicolumn{2}{|l|}{ Occupation (\%) } \\
\hline Permanent work & 65.9 \\
\hline Not work & 34.1 \\
\hline \multicolumn{2}{|c|}{ Level of Education (\%) } \\
\hline Elementary & 38.3 \\
\hline Senior High School & 48.9 \\
\hline College & 12.8 \\
\hline
\end{tabular}

Table 2. Patients' Score of QoL domains

\begin{tabular}{lccc}
\hline Domain & \multicolumn{2}{c}{ Score of QoL $(\mathrm{X} \pm \mathrm{SD})$} \\
& Patients with ADR $(\mathrm{n}=10)$ & $\begin{array}{c}\text { Patients without ADR } \\
(\mathrm{n}=38)\end{array}$ & P value \\
\hline Physical Function & $77.5 \pm 28.89$ & $81.0 \pm 19.60$ & 0.66 \\
Limited role-Physical Function & $77.5 \pm 29.90$ & $83.1 \pm 29.45$ & 0.60 \\
Pain & $78.6 \pm 30.44$ & $74.8 \pm 24.58$ & 0.69 \\
General Health & $60.0 \pm 14.52$ & $65.6 \pm 13.06$ & 0.25 \\
Energy & $65.6 \pm 17.23$ & $60.8 \pm 15.74$ & 0.42 \\
Social Function & $78.4 \pm 21.80$ & $84.2 \pm 19.57$ & 0.41 \\
Mental Health & $79.0 \pm 35.91$ & $89.2 \pm 23.67$ & 0.33 \\
Limited role-mental health & $75.2 \pm 10.29$ & $76.5 \pm 15.06$ & 0.79 \\
\hline
\end{tabular}


There were 10 patients experienced ADR and 38 patients are without ADR. The description of QoL domains based on the patients with and without ADR can be seen in Table 2 .

In general, all domains of QoL' scores in patients without ADR is higher than those in patients with ADR. Only pain and energy domains which showed lower score of patients without ADR than patients with ADR. The domain of general health, which means the assumption of patients to their general health in patients without ADR has higher score. Eventhough, the statistical analysis shows non significant results, however, the scores can give description that ADR may affect patients' Qol. This study results is in line with previous study in China, which reported that the use of herbal medicine may exacerbate ADR during the treatment of antiretroviral, eventhough the Qol did not differ significantly (Bepe et al, 2011).

Previous study in China about the use of herbal medicine in advanced non-small cell lung cancer showed that the use of herbal medicine was well tolerated and could improve their qol, since there were no serious adverse effect reported (Han et al, 2015). This could be also happened in our study, that the adverse drug reactions experienced by the patients are not in serious cathegory. Thus, the score of QoL domains did not differ significantly between two groups. Most of the patients experienced pruritus due to the Tensigard and they could overcome the problem by themselves. The other ADR experienced by patients are dizzines, nausea, tachicardia and diarrhea. In other disease, Diabetes melitus, some domain such as: vitality, pain, mental health, general health and physical function were significant different compared to the Diabetes melitus patient with allopathic treatment (Rani et al, 2014).

Our study has some limitation, firstly we conducted this study in retrospective approach, which means that the possibility of recall bias might be appear, especially in answering the QoL questionnaire. Secondly, this study was performed with small sample size. Herbal medicine prescriptions are still rare in Indonesia because the herbal medicine prescription is still not being involved in the health care system in Indonesia. Thirdly, we can not control other variables which could be exacerbate the ADR such as the way of storage, preparation and administration the herbs.

\section{CONCLUSION}

There are no significant differences of quality of life between patients with and without ADR. In general, the quality of life of patients' without ADR is higher than patients with ADR.

\section{ACKNOWLEDGEMENT}

We thank to the staff of Gondomanan and Kasihan Public Health Center, Yogyakarta.

\section{CONFLICT OF INTEREST}

The authors have no conflict of interest.

\section{REFERENCES}

Anonim, Laporan Akuntabilitas Kerja, 2013. Direktorat Bina Pelayanan Kesehatan Tradisional, Alternative dan Komplementer, Jakarta.

Badan Pusat Statistik (BPS). 2016. Data sensus.

https://www.bps.go.id/index.php/istilah/i ndex?Istilah_page $=4$, Accessed 12 February, 2016

Bepe, N., Madhani, N., Mudzviti, T., Gavi, S., Maponga, C.C., Morse, G.D., 2011. The impact of herbal remedies on adverse effects and quality of life in HIVinfected individuals on antiretroviral therapy. J. Infect. Dev. Ctries., 5(1), 4853.

Chan, K.K.L., Yao, T.J., Jones, B., Zhao, J.F., Ma, F.K., Leung, C.Y., 2011. The use of Chinese herbal medicine to improve quality of life in women undergoing chemotherapy for ovarian cancer: a double-blind placebo-controlled 
randomized trial with immunological monitoring. Ann. Oncol.

Han, Y., Wang, H., Xu, W., Cao, B., Han, L., Jia, L., et al., 2016. Chinese herbal medicine as maintenance therapy for improving the quality of life for advanced non-small cell lung cancer patients. Complement. Ther. Med., 24, 55-62.

Mutmainnah, 2009. Pemanfaatan Jamu Madura oleh Perempuan di Kabupaten Bangkalan. Masyarakat, Kebudayaan dan Politik, 2,121-127.

Naja F, Fadel RA, Alameddine M, Aridi Y, Zarif A, Hariri D. et al., 2015. Complementary and alternative medicine use and its association with quality of life among Lebanese breast cancer patients: a cross-sectional study. BMC Complement. Altern. Med., 22, 444.

Rani MS, Pippalla RS, Mohan GK, Gaikwad SB, Prasad B. 2015. A Comparative Quality of Life Assessment of Herbal Drugs with Allopathic Drugs for the
Treatment of Diabetic Complications. Pharmaceutical Crops., 5 (Suppl 1: M7), 77-84

Sugimoto N, Ichikawa M, Siriliang B, Nakahara S, Jimba M, Wakai S., 2005. Herbal medicine use and quality of life among people living with HIV/AIDS in northeastern Thailand. AIDS Care., 17 (2), 252-262.

Suhadi, R., Linawati, Y., Virginia, D.M., and Setiawan, C.H., 2015. The Early Implementation of Universal Health Coverage Among the Hypertension Subjects in the Sleman-District of Yogyakarta. Acta Med Indones., 47 (4), 311-319.

Wu X, Chung VCH, Lu-Poon SK, Hui EP, Lau AYL, et al., 2016. Chinese Herbal Medicine for Improving Quality of Life Among Nonsmall Cell Lung Cancer Patients Overview of Systematic Reviews and Network Meta-Analysis. Medicine (Baltimore)., 95: e2410. 